\title{
Variation in Randomly Amplified DNA Markers and Storage Root Yield in 'Jewel' Sweetpotato Clones
}

\author{
Arthur Q. Villordon ${ }^{1}$ and Don R. LaBonte ${ }^{2}$ \\ Department of Horticulture, Louisiana Agricultural Experiment Station, Louisiana State University \\ Agricultural Center, Baton Rouge, LA 70803 \\ Additional index words. lpomoea batatas, arbitrary primers, putative polymorphisms, foundation seed program, clonal \\ variability

\begin{abstract}
Polymorphism analysis and yield tests were conducted among 'Jewel' sweetpotato clones [ Ipomoea batatas (L.) Lam] obtained from eight state foundation seed programs. Initially, 38 arbitrary primers generated a total of 110 scorable DNA fragments in a sample of virus-indexed plants from each clone source. The number of marker loci scored for each primer varied from one to eight with an average of 2.89 . Twenty-one bands $(\mathbf{1 9 . 1 \% )}$ were scored as putative polymorphic markers based on the presence or absence of amplified products. Further estimation of variability within each clone source was accomplished by an assay of 10 sample plants per clone group by 14 marker loci generated by four selected primers. Polymorphic bands ranged from $7.1 \%$ to $35.7 \%$ in five of eight clone groups. Field studies show variation in nearly all yield grades measured. In three tests during the 1991 and 1992 seasons, yield differences ranged from $27 \%$ to $46 \%$ within the economically important U.S. no. 1 root grade. The results suggest the usefulness of arbitrarily-primed markers in detecting intra-clonal sweetpotato DNA polymorphisms and indicate an underlying genetic cause for phenotypic variability in the crop.
\end{abstract}

Asexual propagation theoretically preserves genotypic identity and uniformity within a clonal cultivar. In the sweetpotato, the zygotic stage determines a cultivar's genotypic constitution; ensuing mitotic duplications perpetuate this unique genetic makeup. Adventitious sprouts derived from fleshy roots of sweetpotato are used for vegetative propagation, hence conservation of cultivar genetic identity is expected. However, phenotypic plasticity especially in quantitatively inherited traits is expected due to environmental effects. Several reports document the magnitude of environmental influence, expressed as genotype $\times$ environment interactions, in sweetpotato phenotypic expression (Collins et al., 1987; Huett, 1976; Kannua and Floyd, 1988; Ngeve and Bouwkamp, 1993). Nevertheless, the yield of a well-established sweetpotato cultivar can range from zero to several kilograms per plant. Slight differences in size and quality among sprouts or cuttings used in plantings cannot account for all of this observed variability (Hwang et al., 1983; Steinbauer et al., 1943). More importantly, visible qualitative variability such as root, skin, and flesh color changes are common. For instance, flesh color mutation rates in sweetpotato range between $1 \%$ and $18 \%$, depending on the cultivar (Hernandez et al., 1964). In contrast, the estimated mutation rate in clonally- propagated potato (Solanum tuberosum) is one in 100,000 to 200,000 plants (Heiken, 1958). Consequently, sweetpotato foundation seed programs allocate substantial resources in maintaining the genetic uniformity of cultivars.

State foundation programs continue to maintain the genetic identity of sweetpotato cultivars using a visual selection procedure

Received for publication 7 Nov. 1994. Accepted for publication 6 Apr. 1995. Approved for publication by the director of the Louisiana Agricultural Experiment Station as manuscript no. 94-Z-8018. The research was supported by funds from the Louisiana Methodist World Hunger Scholarship Program, the Louisiana Sweetpotato Advertising and Development Commission, and by state and matching funds allocated to the Louisiana State Univ. (LSU) Agricultural Center. We acknowledge the help of Michael Stine, LSU School of Forestry, Wildlife, and Fisheries (SFWF), for access to the software program used in molecular marker analysis. We also thank Thomas Kubisiak, former graduate assistant in LSU SFWF, for technical suggestions. The cost of publishing this paper was defrayed in part by the payment of page charges. Under postal regulations, this paper therefore must be hereby marked advertisement solely to indicate this fact.

Graduate student.

${ }^{2}$ Associate professor.
(Dangler, 1994). Individual plants or hills of roots most phenotypically representative of a given cultivar are selected from foundation fields, and used as initial source of propagation material for the following year. Although this selection method is subjective, such an approach eliminates most visible phenotypic variants and ensures predictable performance, even though empirical evidence indicates that overall cultivar productivity may decline over time. 'Centennial,' a cultivar released in 1960 by the Louisiana Agricultural Experiment Station, has been grown annually in replicated plots since 1958 at the Sweetpotato Research Station at Chase, La., and its yield has declined by $46 \%$ over a 35 -year period (unpublished data). This evidence is circumstantial due to varied plot location and changes in environment and cultural practices over time, but it illustrates the potential loss that can occur in a highly productive cultivar that is intensively selected. As expected, phenotypic selection does not detect all mutation events. This is evident by the continued appearance of off-types in foundation seed programs.

Although foundation seed providers have been in operation since the 1950s, the effectiveness of these programs in preserving the genetic constitution of specific cultivars has not been fully documented. Benchmark information is important for the following reasons: 1) assessing the efficiency of current maintenance procedures and 2) determining the need for more thorough investigation of genotypic variability within sweetpotato clones. Genotypic uniformity within a clonal cultivar depends on nucleotide sequence similarity at the molecular level. In the absence of molecular sequence data, indirect measures of determining genotypic differences that reflect underlying base pair variability are used (Nienhuis et al., 1993). These include restriction fragment length polymorphism (RFLP) analysis, variable number of tandem repeats (VNTR) fingerprinting, and polymerase chain reaction (PCR)-based techniques. In this study, we investigated the usefulness of a PCR-based polymorphism assay using arbitrary primers (Welsh and McClelland, 1990; Williams et al., 1990) in the hexaploid sweetpotato. Our objectives included the following: assess the usefulness of arbitrary primers in detecting DNA polymorphisms within the 'Jewel' sweetpotato clone, and conduct separate yield tests to determine the range of productivity in this 
cultivar. We chose 'Jewel' since several foundation seed programs have maintained this cultivar for at least 10 years following its release by the North Carolina State Univ. Agricultural Experiment Station in 1969.

\section{Materials and Methods}

Plant material. A sample of 'Jewel' fleshy roots were obtained from each of the following foundation seed programs in eight states: Alabama, California, Georgia, Louisiana, Mississippi, North Carolina, South Carolina, and Virginia. The roots were acquired and bedded in 1990. Sprouts arising from these roots were cut (15$20 \mathrm{~cm}$ ) and planted to increase the number of fleshy roots from each foundation program. This phase was also undertaken to eliminate any environmentally-induced differences among clonal stocks. Only U.S. no. 1 grade roots $(5.1$ to $8.9 \mathrm{~cm}$ in diameter and 7.6 to $22.9 \mathrm{~cm}$ in length) were saved for bedding the following spring (1991) and in all subsequent years. Only sprouts (transplants) of uniform length $(15-20 \mathrm{~cm})$ were used in field plantings.

Two sets of plant material were used in this study. The first sample set consisted of two virus-indexed, meristem-cultured plants of each clone source $(n=16)$. Plants were randomly collected from 1992 field beds, and transferred to a screenhouse for virus indexing. FAO/IBPGR guidelines were used for virus indexing (Moyer et al., 1989). This step eliminated the exopathogen Fusarium lateritium Nees:Fr., and any DNA-based virus or viruslike organism that might amplify and confound data analysis. The second sample set consisted of 10 clonal plants traceable to the original fleshy roots derived from each clone source $(n=80)$, and were randomly collected from 1994 field beds.

DNA extraction. Total DNA was isolated based on the method of Saghai-Maroof et al. (1984) as modified by Jarret and Austin (1994). Genomic DNA was extracted from $2 \mathrm{~g}$ of fresh leaf tissue from each plant. Leaf tissue was ground to a fine powder in liquid nitrogen. An isolation buffer $\left(5 \mathrm{ml} \cdot \mathrm{g}^{-1}\right.$ fresh weight) $(50 \mathrm{~mm}$ Tris/ $\mathrm{HCl} \mathrm{pH}$ 8.0, 25 mM EDTA pH 8.0, 0.35 mm sorbitol, 5\% (PVP-40) polyvinylpyrolidone, $1 \%$ sodium bisulfite, and $0.2 \%$ of $2-$ mercaptoethanol) was added to the powder and centrifuged at $2000 \times \mathrm{g}$ for $10 \mathrm{~min}$ at $4 \mathrm{C}$. The supernatant and all loose debris were discarded. The pellet (crude nuclei) was resuspended in extraction buffer $\left(5 \mathrm{ml} \cdot \mathrm{g}^{-1}\right.$ fresh weight) $(100 \mathrm{~mm}$ Tris $/ \mathrm{HCl} \mathrm{pH} \mathrm{8.0,1.4} \mathrm{M}$ $\mathrm{NaCl}, 20 \mathrm{~mm}$ EDTA, $2 \%$ hexadecyltrimethylammonium bromide, and $1 \%$ of 2-mercaptoethanol) followed by incubation in $60 \mathrm{C}$ for $30-60 \mathrm{~min}$. An equal volume of 24 chloroform : 1 isoamyl alcohol (v/v) was used for extraction for 5 min with slow but constant inversion, and phases were separated by centrifugation at $5,000 \times$ $\mathrm{g}$ for $10 \mathrm{~min}$ at room temperature. The aqueous phase was removed and transferred to a new tube for DNA precipitation. About twothirds volume of isopropanol was added, and the tube was inverted quickly several times until the DNA precipitated and then re-

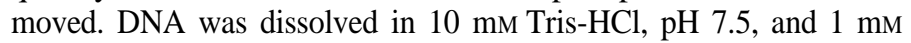
EDTA, and then quantified using a UV-VIS spectrophotometer (Perkin Elmer, Norwalk, Conn.).

Arbitrary primers and amplification conditions. DNA polymorphism analysis was conducted in two phases. The initial phase involved an assay of virus-free plants in the first sample set $(n=16)$ using 40 decamer primers from kits A and F (Operon Technologies, Norwalk, Conn.). This phase was conducted in part to determine the subset of marker loci to be used for polymorphism tests in the second sample set $(n=80)$. Primers used in the second sample set were chosen based on the ability to produce at least one putative polymorphic marker locus and reproducibility of amplification. Accordingly, a sample of 14 marker loci produced by primers OPA-07
(5'GAAACGGGTG3'), OPA-09 (5'GGGTAACGCC3'), OPA-10 (5'GTGATCGCAG3'), and OPF-05 (5'CCGAATICCC3') was selected. These marker loci, scored between 1018 and 298 base pairs (bp), represent about half of the total number of fragments produced by these arbitrary primers. DNA samples of 'Beauregard' and 'Centennial' cultivars were included in the second sample set as control fragment patterns and for outgroup comparisons.

GeneAmp PCR Reagent Kits (Perkin Elmer Applied Biosystems, Foster City, Calif.) were used in all reaction mixes. Reaction conditions were similar to those reported by Williams et al. (1990), except that we used 1.5 unit of Taq Stoffel fragment (Perkin-Elmer Applied Biosystems, Foster City, Calif.). PCR conditions consisted of 10mm Tris-HC1, $\mathrm{pH} 8.2,50 \mathrm{~mm} \mathrm{KC1}, 2 \mathrm{mM} \mathrm{MgCl}_{2}, 0.001 \%$ gelatin, $0.1 \mathrm{~mm}$ of each of dATP, dCTP, dTTP, dGTP, $0.2 \mu \mathrm{M}$ primer, and $25 \mathrm{ng}$ genomic DNA per $2.5 \mu \mathrm{l}$ reaction volume. The reaction mixture was placed in a $0.5 \mathrm{ml}$ plastic reaction tube and overlaid with $25 \mu \mathrm{l}$ of mineral oil. DNA was amplified in a thermal cycler (model 480; Perkin Elmer) programmed for 40 cycles of 1 min at $94 \mathrm{C}, 1 \mathrm{~min}$ at $35 \mathrm{C}, 2 \mathrm{~min}$ at $72 \mathrm{C}$, followed by a final extension at $72 \mathrm{C}$ for $7 \mathrm{~min}$, and then held at $4 \mathrm{C}$ until recovery. Amplified DNA fragments were resolved by electrophoresis $(3 \mathrm{v} / \mathrm{cm})$ for $4 \mathrm{~h}$ in gels composed of $1.2 \%$ agarose (BRL, Bethesda, Md.) in $1 \times$ TAE buffer $(0.04 \mathrm{M}$ Tris-acetate and $0.001 \mathrm{M}$ EDTA $)$ in the presence of $0.5 \mu \mathrm{g} \cdot \mathrm{ml}^{-1}$ ethidium bromide, and photographed under UV light. The presence or absence of bands between 0.17 and $2 \mathrm{~kb}$ were scored from photographs. Nomenclature for marker loci represents the Operon Primer kit designation plus the estimated fragment size in base pairs (bp). A molecular weight marker (1 Kb DNA ladder, BRL) was used in visually estimating fragment size.

Analysis of amplified DNA fragments. Only fragments common in both sample sets were scored. This reduces background "noise" by possible pathogenic and viral infections of plants in the second sample set. Such introduced DNA sequences can result in amplification of artifacts (Newbury and Ford-Lloyd, 1993) that confound results and lead to erroneous interpretations. DNA extract from an infected sweetpotato sample plant can produce a unique amplified fragment not found in a pathogen-free DNA sample (unpublished data). Variability in both sample sets was expressed as percent polymorphism computed as the number of putative polymorphic markers over the total number of markers scored. In addition, fragment data in the second sample set were treated as two-state qualitative data from which genetic similarity measurements were estimated. Band data were coded as one (presence of band) and zero (absence of band) and entered into a numerical taxonomy and multivariate analysis system (NTSYS-pc), version 1.8 (Applied Biostatistics, Setauket, N.Y.). Analysis was done using similarity for qualitative data (SIMQUAL) routine to generate Dice's similarity coefficient. A triangular matrix of pairwise similarity values was generated. This matrix was subjected to a principal components analysis and a multidimensional scaling (MDSCALE) algorithm from the NTSYS-pc software package.

Yield comparisons. All yield tests used a randomized complete block design with eight blocks and guard rows of 'Jewel' surrounding each planting. Twenty transplants per plot were placed $0.3 \mathrm{~m}$ apart within rows and $1.2 \mathrm{~m}$ between rows in Evangeline Parish in 1991 and 1992, and at the Burden Research Plantation, Baton Rouge, La. in 1992. These plantings were harvested after 100 and 128 days in Evangeline Parish, respectively, and 134 days at Baton Rouge.

Roots were graded and weighed into U.S. no. 1, canner $(2.5$ to $5.1 \mathrm{~cm}$ in diameter and 5.1 to $17.8 \mathrm{~cm}$ in length), and jumbo (larger than both groups but marketable). Data were subjected to an ANOVA, and residual analysis was conducted to determine normality of data and homogeneity of variances (SAS, 1987). 


\section{Results}

Amplified DNA markers. In the first sample set $(\mathrm{n}=16)$, all primers generated fragments detected by gel electrophoresis following staining of gels with ethidium bromide. The size of the fragments ranged from $200 \mathrm{bp}$ (A03) to 3,800 bp (A12). Of these, 38 primers produced a total of 110 storable markers. The number of markers scored for each primer varied from one (A-17, A-20, A$10)$ to eight (A-01) with an average of 2.89 bands per primer. The majority of scored bands are in the smaller fragment range, consistent with other reports concerning the use of Taq Stoffel fragment in arbitrarily-primed DNA amplification assays (Sobral and Honeycutt, 1993). This phenomenon is ascribed to the lower processivity of the Stoffel fragment compared with the native Taq enzyme (Erlich et al., 1991).

In the first sample set $(n=16), 21$ bands $(19.1 \%)$ were present in some clones but absent in others and thus were scored as putative polymorphic markers (Table 1, Fig. 1A). The presence or absence of bands was scored at markers A07-570, A07-506, and A07-451 (corresponding to about 570,506, and $451 \mathrm{bp}$, respectively); amplitied fragments at A07-344 were scored as monomorphic bands (Fig. IA). Similarly all bands at A08-451, A08-298, and A08-259 bp were scored asmonomorphic bands (Fig. 1B). Faint bands associated with both primers and other primers were not scored.

Variability within and between clone groups was detected in the second sample set $(\mathrm{n}=80)$. Polymorphic marker loci ranged from $7.1 \%$ to $35.7 \%$ in five of eight groups of clones. Alabamaand Georgia DNA samples had zero polymorphic markers whereas Mississippi and North Carolina each had 14.2\% polymorphism. California, South Carolina, and Virginia had 28.6\%, 35.7\%, and $21.1 \%$ polymorphic loci, respectively. LA was uniquely monomorphic within the clone group but differed as a unit by $14.2 \%$ from most samples monomorphic for all marker loci.

Using fragment data from the second sample set, a $21 \times 21$ triangular matrix of similarity values was generated using the SIMQUAL = Dice option of NTSYS-pc (data not shown). The matrix of genetic similarity measures was subjected to principal components analysis and MDSCALE algorithm in NTSYS-pc. In principal component analysis, the first and second components accounted for at $79.4 \%$ and $7.8 \%$ of the variance, respectively. We present the results of the MDSCALE (number of dimensions in configuration space $=3$ ) analysis using the MOD3D graphing program in the NTSYS-pc software package (Fig. 2).

Plots of putative 'Jewel' variants (shaded circles) are found in the hyperspace about the data point (solid circle) that represents most samples monomorphic for marker loci (Fig. 2). This invariant data point can be interpreted as the putative 'Jewel' DNA fragment fingerprint based on the sample marker loci. Two separate clusters are found in this hyperspace: one group includes CA11, MS3, MS7, NC6, SC6, and SC11; the other cluster includes CA3, SC2, SC5, SC10 and VA11. The LA (LA1-10) data point (solid circle) represents 10 samples that differentiated as a group from the 'Jewel' fingerprint.

Storage root yield. A summary of mean root yield by grade within each location and year is presented in Table 2. In general, the ANOVA detected significant differences among yield grades within each environment. However, no first order interactions (location $\mathrm{x}$ clone source, year x clone source) were observed. The highest and lowest yielders in all grades are significantly different within each year and location except canners in the 1992 Evangeline Parish plot. Variation in yield of the U.S. No. no. 1 grade ranged from $27 \%$ in Burden to $45 \%$ in Evangeline. Similarly, total marketable yield varied by $24 \%$ in the 1992 Evangeline plot to $34 \%$ in the 1991 Evangeline Parish experiment.

Table 1. Survey of 21 polymorphic arbitrarily-primed amplified DNA markers in eight sample 'Jewel' sweetpotato clones from the first sample set used in the study.

\begin{tabular}{|c|c|c|c|c|c|c|c|c|}
\hline \multirow{2}{*}{$\begin{array}{l}\text { DNA } \\
\text { marker }^{y}\end{array}$} & \multicolumn{8}{|c|}{ Clone source } \\
\hline & Ala. & Calif. & Ga. & La. & Miss. & N.C. & S.C. & Va. \\
\hline$\overline{\mathrm{AO} 3-298}$ & + & + & + & + & + & + & - & + \\
\hline $\mathrm{AO} 7-506$ & - & - & - & + & - & - & - & - \\
\hline $\mathrm{AO} 7-570$ & + & + & + & - & - & + & + & + \\
\hline $\mathrm{AO} 7-451$ & + & + & + & - & + & + & + & + \\
\hline A09-634 & + & + & + & + & + & - & + & + \\
\hline A10-570 & - & - & - & + & + & + & + & + \\
\hline A12-298 & + & + & + & - & + & + & + & + \\
\hline A14-396 & + & + & + & + & + & + & + & - \\
\hline A15-259 & + & + & + & + & - & + & + & - \\
\hline A15-220 & + & + & + & + & - & + & + & - \\
\hline A17-890 & + & + & + & - & + & + & + & + \\
\hline A19-698 & + & - & + & - & - & - & + & - \\
\hline FO1-634 & + & + & + & + & + & - & - & + \\
\hline FO5-506 & + & + & + & - & + & + & + & + \\
\hline FO6-762 & - & - & - & + & + & - & + & - \\
\hline FO9-201 & + & + & + & + & - & + & + & - \\
\hline F11-570 & - & - & - & + & - & - & - & - \\
\hline F14-826 & + & - & - & - & - & - & - & - \\
\hline F14-210 & - & + & + & + & + & + & + & + \\
\hline F17-670 & + & + & + & + & + & - & - & + \\
\hline F19-826 & + & + & + & + & + & - & - & + \\
\hline
\end{tabular}

${ }^{2}(+)$ Presence of amplified product, (-) absence of amplified product.

${ }^{\text {}}$ Provisional marker designation represents Operon primer kit designation plus the estimated fragment size in bp. 
(a)

(b)

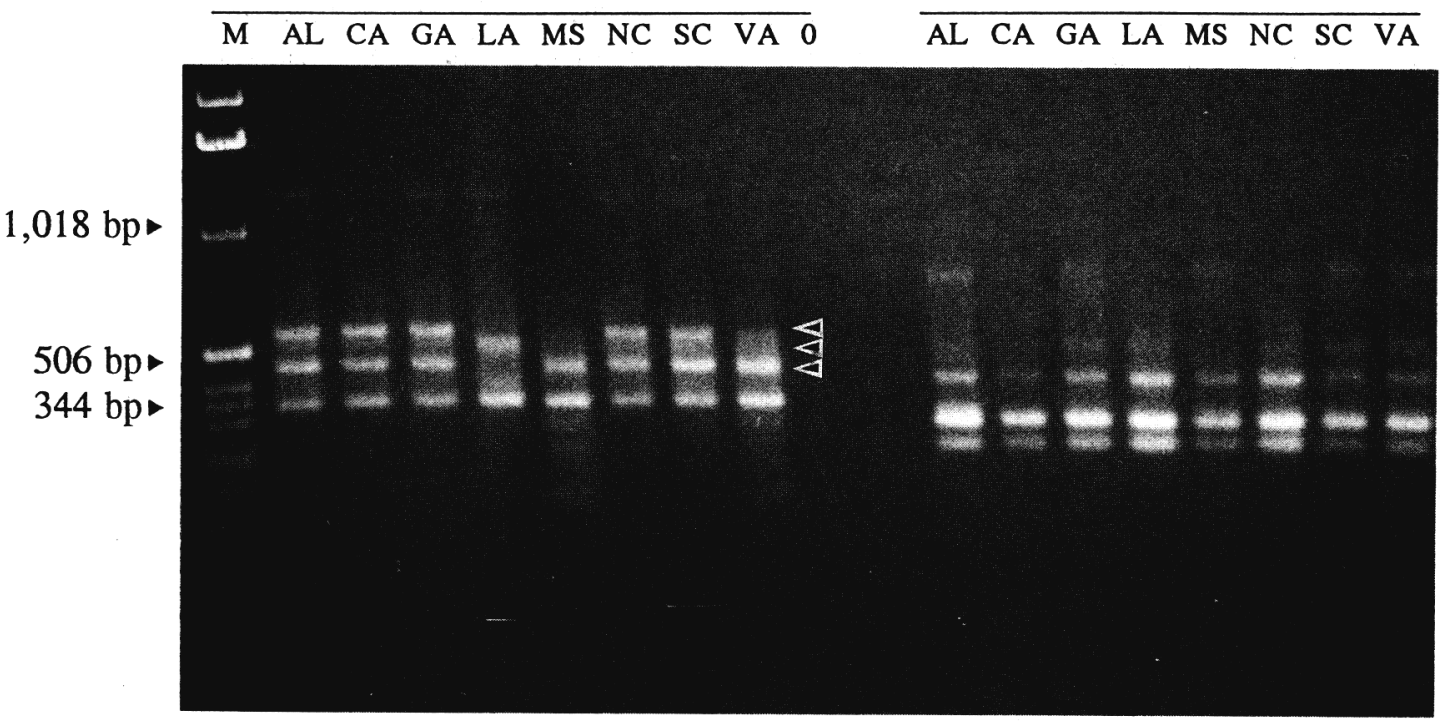

Fig. 1. Ethidium bromide stained amplification products from sample genomic DNA of sweetpotato 'Jewel' clones obtained from eight sources using primers OPA-07 (GAAACGGGTG) (a) and OPA-08 (GTGACGTAGG) (b). Lane 0 corresponds to control reaction without any template DNA. Molecular weight marker (1 Kb DNA ladder, BRL) is shown in lane M. Putative polymorphic bands (indicated by arrowheads) correspond to DNA fragments A07-506, A07-570, and A07-451. Visual comparison with molecular weight markers determines approximate DNA fragment molecular weight.

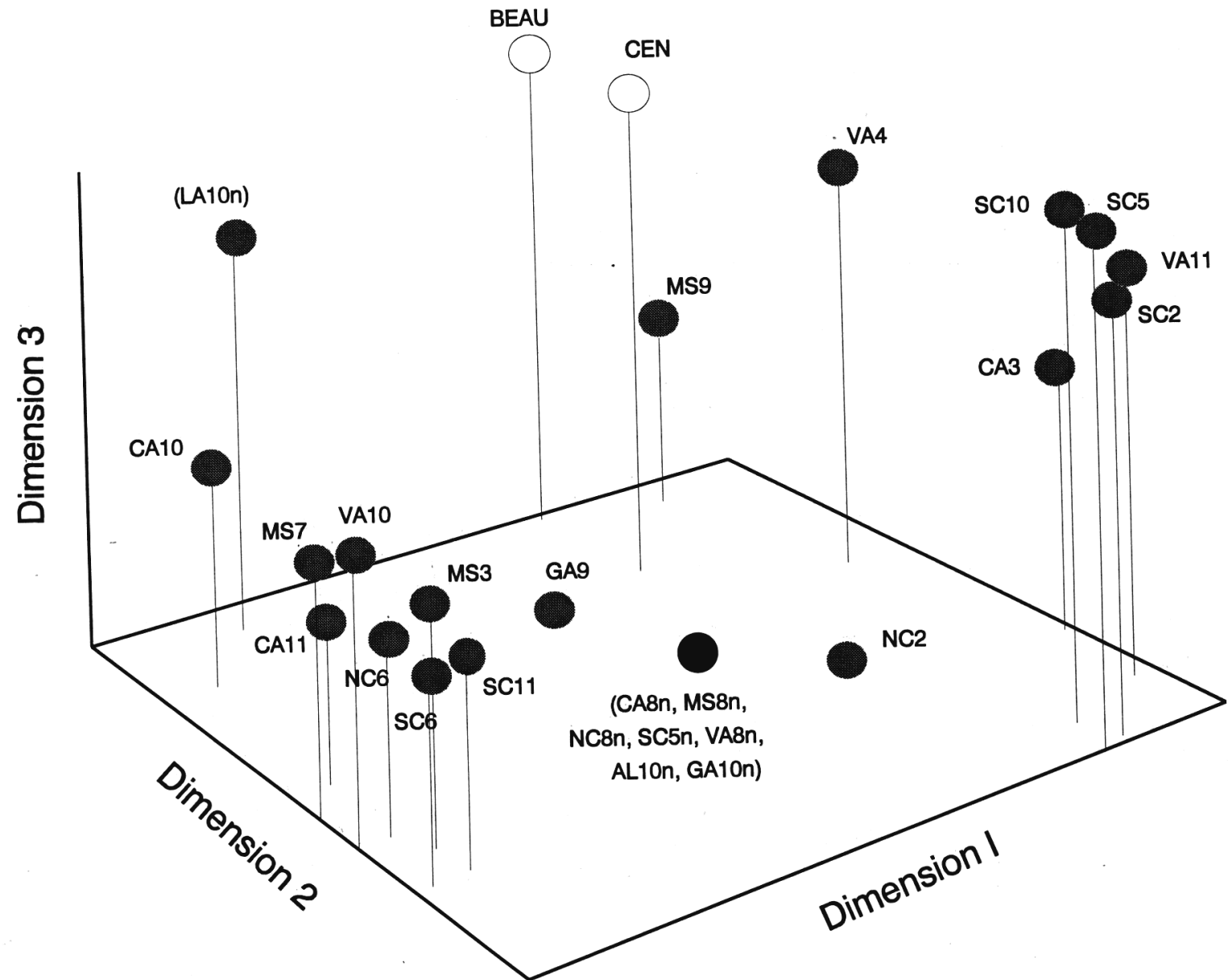

Fig 2. Three-dimensional graph of MDSCALE analysis for genetic similarity values of the second sample set. Multipledatapoints (solidcircle).are defined by clone source abbreviation followed by a numeral + " $n$ " suffix, indicating number of invariant samples. Designations representing multiple dam points are enclosed in parentheses. Putative marker variants (shaded circles) are identified by clone source followed by provisional numerical assignment. BEAU (Beauregard) and CEN (Centennial) (open circles) were entered as control fragment patterns and for outgroup comparison. 


\section{Discussion}

Polymorphic molecular markers. We have shown the suitability of arbitrary primers in detecting DNA polymorphisms in 'Jewel' clones using a small sample size $(n=16)$ with 40 primers, and a relatively large sample size $(n=80)$ with four selected primers. Increasing marker loci in the second sample set will expand coverage of the genome and conceivably detect additional polymorphisms. Arbitrary primers have been shown to randomly sample the whole genome, including high- and middle-repetitive sequences, and single copy DNA (Williams et al., 1990). However, the dominant nature of the markers potentially limits the amount of information from polymorphism analysis using such primers, i.e., inability to distinguish between homozygous and heterozygous loci. In addition, some fragments of similar molecular weight do not necessarily contain homologous DNA segments (Smith et al., 1994). Thus a single amplification product can occasionally represent two or more loci, i.e., smaller fragments that comigrate. Furthermore, multiple genome copies inherent in the hexaploid $(2 n=6 x=90)$ sweetpotato potentially underestimate actual variability due to the technical limitations of scoring polymorphisms based on differential band intensity on agarose gels.

For our purposes, the use of arbitrary primers in detecting intraclonal polymorphisms has yielded promising results, especially in the context of earlier reports on clonal phenotypic variability. Molecular markers provide estimates of genomic variability that are independent of confounding environmental effects and should be incorporated as tools in thoroughly assessing the nature of variability in the sweetpotato. However, the magnitude of molecular polymorphisms does not necessarily reflect the degree of phenotypic variability. For instance, RFLPs that detected a 75\% reduction of $25 \mathrm{~S}$ ribosomal DNA did not phenotypically differentiate mutants vs. wild type potato plants (Landsmann and Uhrig, 1985). Nevertheless, some RFLP markers were unambiguously correlated with mutated chloroplasts in albino cereal plants regenerated from tissue culture (Day and Ellis, 1985). By efficiently screening primers in segregating plant populations, molecular markers can be linked with qualitatively and quantitatively-inherited economically important phenotypes. For example, bulk segregant analysis has been used to link RAPD markers with disease resistance in lettuce (Michelmore et al., 1991). Furthermore, quantitative trait loci (QTL) analysis with arbitrarily-primed markers is theoretically possible once RAPD-based linkage maps are established ( $\mathrm{Yu}$ et al., 1993). For instance, arbitrary primers detected sufficient polymorphisms in a segregating population of a wild polyploid relative of sugarcane, allowing the placement of markers in linkage groups (Sobral and Honeycutt, 1993).

The MOD3D graph of the MDSCALE analysis identified at least two clusters of putative 'Jewel' genetic marker variants (Fig. 2). Each of these clusters suggest similarity of either variant priming sites or altered intervening segments that are flanked by invariant priming sites. Such sequences can represent repetitive segments or conserved, but highly buffered loci in the sweetpotato hexaploid genome. On the other hand, Louisiana samples differentiated as a whole by two marker loci from the putative 'Jewel' fingerprint. These variant sequences unique to Louisiana could have been fixed by chance, a tenable situation when seed population size is small. The other data points within the hyperspace (CA10, GA9, MS9, NC2, VA4) may represent random changes within the genome detected by primers. 'Centennial' and 'Beauregard' were included in the analysis for outgroup comparisons. 'Centennial' is the paternal parent of 'Jewel' (Nugget $x$ Centennial $=$ Jewel). An unweighted pair-group method (UPGMA)
Table 2. Marketable yields in three locations of 'Jewel' clones obtained from eight foundation seed programs.

\begin{tabular}{|c|c|c|c|c|}
\hline \multirow{2}{*}{$\begin{array}{l}\text { Clone source } \\
\text { location, and } \\
\text { year of trial }\end{array}$} & \multicolumn{4}{|c|}{ Yield $^{\mathrm{z}}\left(\mathrm{t} \cdot \mathrm{ha} \mathrm{a}^{-1}\right)$} \\
\hline & U.S. no. 1 & Canner & Jumbo & TMY \\
\hline \multicolumn{5}{|l|}{ Evangeline (1991) } \\
\hline North Carolina & 11.4 & 6.9 & 0.0 & 18.3 \\
\hline Mississiippi & 9.9 & 6.2 & 0.0 & 16.2 \\
\hline South Carolina & 8.0 & 6.9 & 0.0 & 14.9 \\
\hline Louisiana & 9.6 & 5.1 & 0.0 & 14.7 \\
\hline Virginia & 8.4 & 5.5 & 0.0 & 13.9 \\
\hline California & 9.2 & 4.1 & 0.0 & 13.3 \\
\hline Georgia & 8.2 & 4.9 & 0.0 & 13.1 \\
\hline Alabama & 6.1 & 5.8 & 0.0 & 11.9 \\
\hline $\operatorname{LSD}(5 \%)$ & 4.3 & 2.2 & 0.0 & 5.2 \\
\hline \multicolumn{5}{|l|}{ Evangeline (1992) } \\
\hline Louisiana & 25.7 & 8.9 & 5.5 & 40.2 \\
\hline California & 25.3 & 9.2 & 2.3 & 36.8 \\
\hline Virginia & 22.9 & 8.8 & 2.9 & 34.7 \\
\hline Alabama & 22.9 & 9.5 & 1.5 & 33.9 \\
\hline North Carolina & 22.6 & 9.5 & 1.6 & 33.8 \\
\hline Mississippi & 22.4 & 7.9 & 2.0 & 32.4 \\
\hline Georgia & 21.4 & 8.6 & 0.3 & 30.3 \\
\hline South Carolina & 18.5 & 10.7 & 0.9 & 30.2 \\
\hline $\operatorname{LSD}(5 \%)$ & 4.3 & 2.6 & 5.7 & 5.7 \\
\hline \multicolumn{5}{|l|}{ Burden (1992) } \\
\hline Mississippi & 16.2 & 8.3 & 1.6 & 26.2 \\
\hline South Carolina & 15.3 & 8.1 & 0.5 & 24.8 \\
\hline Alabama & 13.6 & 8.1 & 0.4 & 22.0 \\
\hline Louisiana & 14.6 & 7.4 & 0.0 & 22.0 \\
\hline California & 12.2 & 8.9 & 0.5 & 21.7 \\
\hline North Carolina & 12.1 & 7.8 & 0.6 & 20.4 \\
\hline Virginia & 11.7 & 6.7 & 0.7 & 19.0 \\
\hline Georgia & 13.0 & 5.8 & 0.1 & 18.9 \\
\hline $\operatorname{LSD}(5 \%)$ & 4.5 & 1.97 & 1.3 & 4.3 \\
\hline
\end{tabular}

${ }^{2}$ U.S. no. 1 (5.1-8.9 $\mathrm{cm}$ in diameter; 7.6-22.9 $\mathrm{cm} \mathrm{long),} \mathrm{canner} \mathrm{(2.5-5.1}$ $\mathrm{cm}$ diameter; 5.1-17.8 cm long), jumbo (larger vs. others, but marketable), TMY $=$ total marketable yield.

'Mean separation in columns by LSD, $P \leq 0.05$.

with arithmetic averages clustering of the Dice similarity values (NTSYS-pc) includes the 'Centennial' and all 'Jewel' samples as expected in a separate group from 'Beauregard' (data not shown).

Genetic variability within a clone alter favorable genetic combinations and contribute to cultivar decline in the highly heterozygous sweetpotato. Reduction of productivity in clones has been generally referred to as clonal degeneration in other crops (Simmonds, 1979), more specifically as cultivar running-out in sweetpotato (Miller et al., 1959). Virus infection has also been identified as a factor in plant clonal degeneration (Richards, 1986). Specifically, Gooding (1964) cites virus as the cause of yield decline in a West Indian sweetpotato population. At the same time, Muller (1964) proposed that species without a sexual phase are not only impeded in evolution but also subject to genetic deterioration. He proposed a ratchet mechanism where mutational load can only increase compared with existing levels. This ratchet mechanism was suggested for haploid sexual organisms, but can also apply to diploid and polyploid organisms as long as these mutations are expressed in the heterozygous condition (Leslie and Vrijenhoek, 1980).

The net effect of Muller's ratchet in causing deterioration is a function of genome (more loci to mutate) and population size (Maynard-Smith, 1978). The polyploidnature $(2 n=6 x=90)$ of the 
sweetpotato can contribute to the unusually high rates of visible mutation in the crop. If a constant number of random mutations occur per generation in a haploid genome, then a triploid will experience three mutations for every two experienced by a diploid (Mogie, 1992). Thus, in the hexaploid sweetpotato, six mutation sites are theoretically possible compared to two in a diploid counterpart. At some point, the extra genome dosage may not sufficiently buffer additional deleterious mutations and also the complex interactions among mutant sites, wild type alleles, and the prevailing environment. This is synonymous to attaining a mutation/selection equilibrium in Muller's ratchet mechanism before mutational load increase. Presuming the ratchet mechanism operates, and assuming all deleterious mutations are expressed, then cultivar decline becomes a function of time.

The mode of propagation can also contribute to the crop's predisposition to genetic variability. In tropical propagation systems, the sweetpotato is virtually a perennial, where stem cuttings are collected from standing crops in a continuous planting procedure (Simmonds, 1976). In contrast, the crop is grown as an annual in the United States and in other subtropical production areas. In these areas, the sweetpotato sprout is the unit of propagation. These sprouts are derived from adventitious buds on storage roots. Adventitious buds may develop in callus, wound periderm, the vascular cambium or in anomalous cambia (Edmond and Ammerman, 1971; Fahn, 1982). Adventitious bud production, particularly from callus or anomalous cambia, originate from previously non-meristematic cells. This nonmeristematic origin can contribute to systematic variability in subsequent generations. For example, in vitro cultures established from nonmeristematic tissue in other plant species have a higher rate of variation than cultures from organized tissues (meristems) (D'Amato, 1985). Gould (1984) identified differences in the duration of various phases of cell cycles in meristematic and nonmeristematic dividing cells in tissue cultures of various plants. Such disturbances cause delay in DNA replication in heterochromatic regions and result in genetic variation (Lee and Phillips, 1988). Assuming absence of strictly regulated cell cycles, each round of sweetpotato clonal multiplication potentially introduces subtle variability that may accumulate over time. Hence, certain aspects of the sweetpotato propagation system may resemble somaclonal variation observed in in vitro systems.

Variation in yield. Differences in yield measurements suggest the range of mean productivity among clones. The absence of first order interactions for yield data suggests that the change of mean rankings across environments was not significant, and the differential response among genotypes, without rank change across environments, was also not significant. If root samples are accurate representations of each foundation program, then data can be taken to reflect the range of cultivar yield variability among clone sources ( $27 \%$ to $46 \%$ ) across the sample environments. The differences in mean performance among clonal classes can be attributed to the following factors that act singly orjointly: 1) random and systematic fixation of deleterious and beneficial mutations, 2) interaction between the environment and mutant and wild type alleles, and 3) temporal and spatial variation in size of the source foundation seed populations.

\section{Conclusions}

At the phenotypic and genotypic level, our results suggest inherent variability still exist within clonal samples despite elimination of off-types in the source population. Many of these changes appear to be associated with the polyploid genome and compounded by the nature of the adventitiously-based sweetpotato propagation system. We are currently assessing genetic marker uniformity of seed maintained through nodal culture (meristematic tissue origin) versus the conventional method of maintaining sweetpotato seed (adventitious origin). If propagation system plays an important role in sweetpotato clonal variability, then incorporating a method based on preexisting meristematic tissue may reduce inherent genomic variability within foundation seed programs.

\section{Literature Cited}

Collins, W.W., L.C. Wilson, S. Arrendell, and L.F. Dickey. 1987. Genotype $\mathbf{x}$ environment interactions in sweetpotato yield and quality factors. J. Amer. Soc. Hort. Sci. 112:579-583.

D'Amato, F. 1985. Cytogenetics of plant cell and tissue cultures and regenerants. Crit. Rev. Plant Sci. 3:73-112.

Dangler, J.M. 1994. Sweetpotato foundation programs provide sweetpotato growers with high-quality pathogen-free stock. Compendium sweetpotato foundation programs. HortTechnology 4:224.

Day, A. and T.H.N. Ellis. 1985. Deleted forms of plastid DNA in albino plants from cereal anther culture. Curr. Genet. 9:674-678.

Edmond, J.B. and G.R. Ammerman. 1971. Sweetpotatoes: production, processing and marketing. AVI, Westport, Conn..

Erlich, H.A., D. Gelfand, and J.J. Sninsky. 1991. Recent advances in the polymerase chain reaction. Science 252:1643-1651.

Fahn, A. 1982. Plant Anatomy. Pergammon Press, Oxford, U.K.

Gooding, H.J. 1964. Some aspects of the methods and results of sweetpotato selection. Emp. J. Expt. Agr. 32:279-289.

Gould, A.R. 1984. Control of the cell cycle in cultured plant cells. Crit. Rev. Plant Sci. 1:315-344.

Heiken, A. 1958. Aberrant types in potato. Acta Agr. Stand. 8:319-358. Hernandez, T.P., T. Hernandez, and J.C. Miller. 1964. Frequency of somatic mutations in several sweetpotato varieties. J. Amer. Soc. Hort. Sci. 85:430-433.

Huett, D.O. 1976. Evaluation of yield, variability and quality of sweetpotato cultivars in subtropical Australia. Expt. Agr. 12:9-16.

Hwang, L.S., R.M. Skirvin, J. Casyao, and J. Bouwkamp. 1983. Adventitious shoot formation from sections of sweetpotato grown in vitro. Scientia Hort. 20:119-129.

Jarret, R.L. and D.F. Austin. 1994. Genetic diversity and systematic relationships in sweetpotato (Zpomoea batatas L. Lam) and related species as revealed by RAPD analysis. GRACE. (In press.)

Kannua, M.B. and C.N. Floyd. 1988. Sweetpotato genotype-environment interactions in the highlands of Papua New Guinea. Trop. Agr. 65:9-15.

Landsmann, J. and H. Uhrig. 1985. Somaclonal variation in Solanum tuberosum detected at the molecular level. Theor. Appl. Genet. 71:500505.

Lee, M. and R.L. Phillips. 1988. The chromosomal basis of somaclonal variation. Annu. Rev. Plant Physiol. Plant Mol. Biol. 39:413-437.

Leslie, J.F. and R.C. Vrijenhoek. 1980. Consideration of Muller's ratchet mechanism through studies of genetic linkage and genomic compatabilities in clonally reproducing Poeciliopsis. Evolution 34:1105-1115.

Maynard-Smith, J. 1978. The evolution of sex. Cambridge Univ. Press, London.

Michelmore, R.W., I. Paran, and R.V. Kesseli. 1991. Identification of markers linked to disease-resistance genes by bulked segregant analysis: A rapid method to detect markers in specific genomic regions by using segregating populations. Proc. Natl. Acad. Sci. USA 88:98289832.

Miller, J.C., T.P. Hernandez, T. Hernandez, and R.J. Barry. 1959. Sweetpotato foundation seed program for Louisiana. La. Agr. Expt. Sta. Circ. \#58.

Mogie, M. 1992. Evolution of asexual reproduction in plants. Chapman \& Hall, London.

Moyer, J.W., G.V.H. Jackson, and E.A. Friason. 1989. FAO/IBPGR technical guidelines for the safe movement of sweetpotato germplasm. FAO/UN, IBPGR, Rome.

Muller, H.J. 1964. The relation of recombination to mutational advance. Mutation Res. 1:2-9. 
Newbury, H.J. and B.V. Ford-Lloyd. 1993. The use of RAPD for assessing variation in plants. Plant Growth Regulat. 12:43-51.

Ngeve, J.M. and J.C. Bouwkamp. 1993. Comparison of statistical methods to assess yield stability in sweetpotato. J. Amer. Soc. Hort. Sci. 118:304-310.

Nienhuis, J., M.K. Slocum, D.A. De Vos, and R. Muren. 1993. Genetic similarity among Brassica oleracea L. genotypes as measured by restriction fragment length polymorphisms. J. Amer. Soc. Hort. Sci. 118:298-303.

Richards, A.J. 1986. Plant breeding systems. Allen and Unwin Ltd, London.

Saghai-Maroof, M.A., K.M. Soliman, R.A. Jorgenson, and R.W. Allard. 1984. Ribosomal DNA spacer-length polymorphisms in barley: Mendelian inheritance, chromosomal location, and population dynamics. Proc. Natl. Acad. Sci. USA 81:8014-8018.

SAS Institute. 1987. SAS/STAT users' guide. release 6.0. SAS Inst., Cary, N.C. Simmonds, N.W. 1979. Principles of crop improvement. Longman, London.

Simmonds, N.W. 1976. Evolution of crop plants. Longman, London.
Smith, J.J., J.S. Scott-Craig, J.R. Leadbetter, G.L. Bush, D.L. Roberts, and D.L. Fulbright. 1994. Characterization of random amplified polymorphic DNA (RAPD) products from Xanthomonas campestris and some comments on the use of RAPD products in phylogenetic analysis. Mol. Phylo. Evol. 3:135-145.

Sobral, B.W.S. and R.J. Honeycutt. 1993. High output genetic mapping of polyploids using PCR-generated markers. Theor. Appl. Genet. 86:105-112.

Steinbauer, C.E., G.P. Hoffman, and J.B. Edmond. 1943. Why are single plant yields of sweetpotato highly variable within plots? J. Amer. Soc. Hort. Sci. 43:249-254.

Welsh, J. and M. McClleland. 1990. Fingerprinting genomes using PCR with arbitrary primers. Nucleic Acids Res. 18:7213-7218.

Williams, J.G.K., A.R. Kubelic, K.J. Livak, J.A. Rafalski, and S.V. Tingey. 1990. DNA polymorphisms amplified by arbitrary primers are useful as genetic markers. Nucleic Acids Res. 18:6531-6535.

Yu, K.F., A.V. Deynze, and K.P. Pauls. 1993. Random amplified polymorphic DNA (RAPD) analysis, p. 287-301. In: Methods in plant molecular biology and biotechnology. CRC Press, Boca Raton, Fla. 